\title{
Relationship between viral and prokaryotic abundance on the Bajo O'Higgins 1 Seamount (Humboldt Current System off Chile)
}

\author{
OSCAR E. CHIANG ${ }^{1}$ and RENATO A. QUIÑNONES ${ }^{1,2}$ \\ ${ }^{1}$ Centro FONDAP-COPAS, Universidad de Concepción, Casilla 160-C, Concepción, Chile. E-mail: ochiang@udec.cl \\ ${ }^{2}$ Departamento de Oceanografía, Universidad de Concepción, Casilla 160-C, Concepción, Chile.
}

\begin{abstract}
SUMMARY: There is little known about the ecology of microbial communities living in the water column over seamounts. Here, for the first time, the spatial distribution and abundance of virus-like particles (VLP) are described over a seamount. The association between VLP distribution, prokaryotic abundance, and environmental variables is also analyzed. Sampling was conducted in December 2004 on the Bajo O'Higgins 1 seamount ( $32^{\circ} 54^{\prime} \mathrm{S}, 7^{\circ} 53^{\prime} \mathrm{W}$ ) located in the Humboldt Current System off Chile. A oxygen minimum layer (OMZ) was clearly present between 130 and $280 \mathrm{~m}$ in the water column over the seamount. Water samples were taken with Niskin bottles at 10 oceanographic stations over the seamount at depths of 5 , $20,50,75,100$, and $150 \mathrm{~m}$ and at the benthic boundary layer (BBL; 5-12 m over the sediments). Temperature, salinity, oxygen, chlorophyll $a$, and phaeopigments were measured at each station. Viral and prokaryotic abundances were determined with fluorochrome SYBR Green I. Viral abundance ranged from $1.53 \times 10^{9} \mathrm{VLP} \mathrm{L}^{-1}-16.48 \times 10^{9} \mathrm{VLP} \mathrm{L}^{-1}$, whereas prokaryotic abundance ranged from $1.78 \times 10^{8}$ cell L-1 $-14.91 \times 10^{8}$ cell $\mathrm{L}^{-1}$. The virus-like particle/prokaryote ratio varied widely among the analyzed layers (i.e. surface, OMZ, and BBL), probably due to the presence of different prokaryotic and viral assemblages in each layer. Our results indicate that the environmental conditions, mainly the concentration of dissolved oxygen in the water column over Bajo O'Higgins 1 seamount, shape the association between viral and prokaryotic abundance.
\end{abstract}

Keywords: virus-like particles, prokaryotes, seamount, oxygen minimum zone, benthic boundary layer, Humboldt Current System.

RESUMEN: RELACIÓN ENTRE LA ABUNDANCIA VIRAL Y PROCARIÓTICA SOBRE EL MONTE SUBMARINO BAJO O'HIGGINS 1 (Sistema DE la CoRriente De Humboldt FRENTE a Chile). - La ecología de comunidades microbianas que habitan en la columna de agua sobre montes submarinos es escasamente conocida. Aquí, por primera vez, se describe la distribución y abundancia de partículas virales (VLP) sobre un monte submarino. La asociación entre la distribución de VLP, abundancia de procariotas y variables ambientales es también analizada. El muestreo fue realizado en Diciembre del 2004 sobre el monte submarino Bajo O'Higgins $1\left(32^{\circ} 54^{\prime} \mathrm{S}, 73^{\circ} 53^{\prime} \mathrm{W}\right)$ localizado en el Sistema de la Corriente de Humboldt frente a Chile. Una zona de mínimo oxígeno se detectó entre 130 y $280 \mathrm{~m}$ en la columna de agua sobre el monte submarino. Las muestras de agua fueron tomadas con botellas Niskin desde 10 estaciones oceanográficas a 5, 20,50,75, 100, y $150 \mathrm{~m}$ de profundidad y en la capa de interfase bentónica (BBL; 5-12 m sobre el sedimento). Las variables temperatura, salinidad, oxígeno, clorofila $a$ y feopigmentos fueron medidas en cada estación. La abundancia de virus y procariotas se determinó utilizando el fluorocromo SYBR Green I. La abundancia viral varió entre $1.53 \times 10^{9} \mathrm{VLP} \mathrm{L}^{-1}-16.48 \times 10^{9} \mathrm{VLP} \mathrm{L}^{-1}$, mientras que la abundancia de células procariotas lo hizo entre $1.78 \times 10^{8}$ células $\mathrm{L}^{-1}-14.91 \times 10^{8}$ células $\mathrm{L}^{-1}$. La razón virus/procariotas varió fuertemente entre los estratos analizados (i.e. superficial, zona de mínimo oxígeno, capa de interfase bentónica), probablemente debido a la presencia de diferentes ensambles procarióticos y virales en cada estrato. Nuestros resultados indican que las condiciones ambientales, principalmente la concentración de oxígeno disuelto en la columna de agua sobre el monte submarino Bajo O’Higgins 1, modula la asociación entre la abundancia viral y la abundancia de células procariotas.

Palabras claves: partículas virales, procariotas, monte submarino, capa de mínimo de oxígeno, capa de interfase bentónica, Sistema de Corriente de Humboldt. 


\section{INTRODUCTION}

Viruses are the most abundant members of aquatic microbial communities (Winter et al., 2005) and their density can exceed bacterial abundance by between 5 and 25 times (Fuhrman, 1999). Although viruses were detected in the marine ecosystem several decades ago (Spencer, 1955; Valentine et al., 1966; Torrella and Morita, 1979; Drake et al., 1998), their importance remained unknown until the microbial loop concept was developed and later refined (Azam et al., 1983). Since then, our understanding of the ecological role that viruses play in the food web and in biogeochemical cycles (Fuhrman, 1999; Weinbauer et al., 2003) has expanded. Viruses are now known to play a fundamental role in controlling prokaryote communities (Bratbak et al., 1990; Fuhrman, 1999), generating mortality rates between 8 and 43\% (Fuhrman, 1999; Winter et al., 2005).

Numerous studies on the distribution of viruses in marine environments have focused mainly on patterns produced by productivity gradients from coastal to oceanic areas (e.g. Weinbauer et al., 1993; Cochlan et al., 1993; Steward et al., 1996; Corinaldesi et al., 2003). It has been shown that viral abundance increases significantly with system productivity (Weinbauer, 2004) and, in accordance with this, it has been proposed that the trophic state of a system is a controlling factor of viral spatial distribution (Corinaldesi et al., 2003). This general tendency, however, has not been contrasted in many marine environments such as seamounts, which influence local circulation and increase the area's biological productivity (e.g. Sime-Ngando et al., 1992). In fact, no quantitative estimate of viral abundance on a seamount has ever been reported to date.

On the other hand, it has been shown that the presence of low oxygen waters and/or strong oxygen gradients in the water column can affect the abundance of virus-like particles (VLP; Taylor et al., 2003; Weinbauer et al., 2003). The oxygen minimum zone (OMZ) of the Humboldt Current System (HCS) is a strong physical barrier for the distribution of many organisms (Antezana, 1978; Judkins, 1980; González and Quiñones, 2002), and the prokaryote community inhabiting it is quite different to that living in the oxygenated surface waters, as shown for archaea (Levipan, 2006), nitrifying communities (Castro-González, 2004), and photosynthetic cyanobacteria (Prochlorococcus sp. and Synechococcus sp.; Ulloa, 2003).
The water column in the case of the Bajo O'Higgins 1 area is influenced by an OMZ and is located over a seamount. Therefore, the relationship between viral abundance and prokaryote abundance is expected to vary considerably in the water column.

This study analyzes the spatial distribution of VLP in relation to (i) prokaryotic abundance and (ii) environmental factors in the water column on the Bajo O’Higgins 1 seamount.

\section{MATERIALS AND METHODS}

\section{Study area}

Samples were taken on the Bajo O'Higgins 1 seamount (32 $\left.{ }^{\circ} 54^{\prime} \mathrm{S}, 7^{\circ} 53^{\prime} \mathrm{W}\right), 135$ miles west of Valparaíso, Chile (Fig. 1). This seamount belongs to the Juan Fernández ridge (Morales, 1985; Arana, 1987), located within the offshore boundaries of the HCS.

\section{Sampling and hydrographic data}

Sampling took place from 24 to 25 December 2004, on board the R/V KOYO MARU (National Fisheries University, Japan). Water samples were taken at 10 stations (bottom depth between 376 and

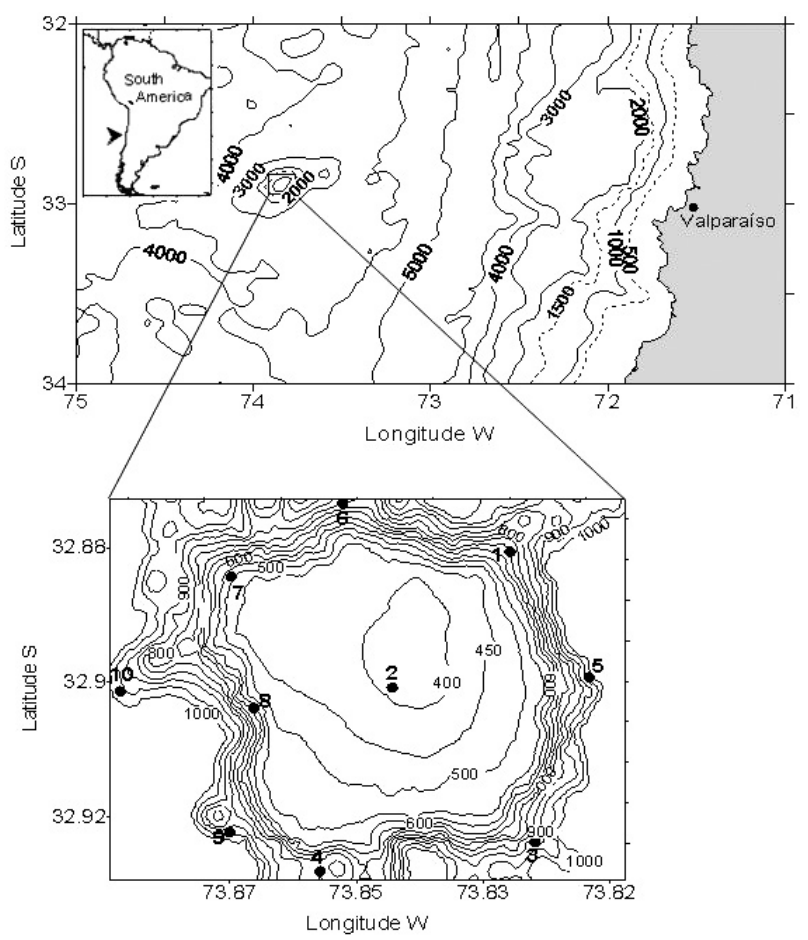

FIG. 1. - Oceanographic stations on Bajo O'Higgins 1 seamount (32 $\left.54^{\prime} \mathrm{S}, 73^{\circ} 53^{\prime} \mathrm{W}\right)$. 
TABLE 1. - Station location, pigment concentrations, and the abundance of virus-like particles and prokaryotes in the benthic-boundary layer (BBL) on the Bajo O'Higgins 1 seamount. n.a. = data not available.

\begin{tabular}{|c|c|c|c|c|c|c|c|c|}
\hline Station & $\begin{array}{l}\text { Latitude } \\
\qquad(\mathrm{S})\end{array}$ & $\begin{array}{l}\text { Longitude } \\
\text { (W) }\end{array}$ & $\begin{array}{l}\text { Station depth } \\
(\mathrm{m})\end{array}$ & $\begin{array}{c}\text { VLP } \\
\left(\mathrm{x} 10^{9} \mathrm{VLP} \mathrm{L}^{-1}\right)\end{array}$ & $\begin{array}{l}\text { Prokaryotes } \\
\left(\mathrm{x} 10^{8} \text { cell } \mathrm{L}^{-1}\right)\end{array}$ & VP-ratio & $\begin{array}{c}\text { Chl } a \\
\left(\mu \mathrm{g} \mathrm{Chl} a \mathrm{~L}^{-1}\right)\end{array}$ & $\begin{array}{c}\text { Phaeop. } \\
\left(\mu \mathrm{g} \mathrm{Ph} \mathrm{L}^{-1}\right)\end{array}$ \\
\hline 1 & $32^{\circ} 53^{\prime} 27^{\prime \prime}$ & $73^{\circ} 52^{\prime} 23^{\prime \prime}$ & 513 & $1.26 \pm 0.18$ & n.a. & n.a. & 0.008 & 0.039 \\
\hline 2 & $32^{\circ} 54^{\prime} 47^{\prime}$ & $73^{\circ} 52^{\prime} 97^{\prime \prime}$ & 376 & $1.41 \pm 0.24$ & $1.72 \pm 0.34$ & 8.18 & 0.019 & 0.063 \\
\hline 3 & $32^{\circ} 55^{\prime} 76^{\prime \prime}$ & $73^{\circ} 52^{\prime} 08^{\prime}$ & 506 & $1.29 \pm 0.18$ & $1.34 \pm 0.29$ & 9.64 & 0.020 & 0.247 \\
\hline 4 & $32^{\circ} 56^{\prime} 62^{\prime}$, & $73^{\circ} 53^{\prime} 80^{\prime \prime}$ & 565 & $0.68 \pm 0.16$ & $1.19 \pm 0.25$ & 5.71 & 0.009 & 0.045 \\
\hline 5 & $32^{\circ} 54^{\prime} 40^{\prime}$ & $73^{\circ} 51^{\prime} 11^{\prime \prime}$ & 562 & $0.76 \pm 0.17$ & $1.14 \pm 0.31$ & 6.62 & 0.006 & 0.047 \\
\hline 6 & $32^{\circ} 52^{\prime} 34^{\prime}$, & $73^{\circ} 53^{\prime} 67^{\prime}$, & 732 & $1.21 \pm 0.15$ & $1.31 \pm 0.32$ & 9.27 & 0.002 & 0.022 \\
\hline 7 & $32^{\circ} 53^{\prime} 41^{\prime}$, & $73^{\circ} 55^{\prime} 18^{\prime}$ & 437 & $0.83 \pm 0.11$ & $1.13 \pm 0.25$ & 7.35 & 0.013 & 0.063 \\
\hline 8 & $32^{\circ} 54^{\prime} 59^{\prime}$, & $73^{\circ} 54^{\prime} 64^{\prime \prime}$ & 448 & $0.72 \pm 0.11$ & $1.27 \pm 0.32$ & 5.63 & 0.011 & 0.048 \\
\hline 9 & $32^{\circ} 55^{\prime} 80^{\prime \prime}$ & $73^{\circ} 55^{\prime} 20^{\prime \prime}$ & 567 & $0.86 \pm 0.14$ & $0.92 \pm 0.17$ & 9.34 & 0.006 & 0.030 \\
\hline 10 & $32^{\circ} 54^{\prime} 54^{\prime}$ & $73^{\circ} 56^{\prime} 34^{\prime}$ & 841 & $0.83 \pm 0.08$ & $0.91 \pm 0.21$ & 9.13 & 0.008 & 0.023 \\
\hline
\end{tabular}

$841 \mathrm{~m}$; see Table 1) over the seamount (Niskin bottles, $2.5 \mathrm{~L}$ ) at the following sampling depths: 5, 20, $50,75,100$, and $150 \mathrm{~m}$. Samples from 5 to $12 \mathrm{~m}$ over the sediments were also taken at all stations and, for practical purposes, will be referred to here as benthic-boundary layer (BBL) samples. Hydrographic data (temperature, salinity, and oxygen) were collected with a CTD Sea Bird Electronics SBE 9.

\section{Chlorophyll $a$ and phaeopigments}

For each depth, $500 \mathrm{ml}$ of water was filtered through a Whatman GF/F filter and then immediately frozen until processing. Pigments were extracted in acetone $(90 \%)$ for $24 \mathrm{~h}$, in the dark, at $-20^{\circ} \mathrm{C}$, and then determined using a fluorometer (TD-700 Turner Designs) according to Parson et al. (1984).

\section{Virus-like particles (VLP) and prokaryotic abundance}

Water samples for counting VLP and prokaryote cells were fixed immediately on board with glutaraldehyde ( $2 \%$ final concentration) and stored in the dark at $4^{\circ} \mathrm{C}$ until analyzed. The samples were processed within 10 days. As described by Noble and Fuhrman (1998), $3 \mathrm{ml}$ were filtered $(0.02 \mu \mathrm{m}$ pore diameter; Anodisc) and stained with fluorochrome SYBR Green I (stock 10\%). The membranes were incubated in the dark for 10 minutes and then mounted on slides with a drop of buffer solution (50\% glycerol, $50 \%$ sodium phosphate buffer, $0.1 \%$ pphenylenediamine). VLP and prokaryote cell abundances were determined by counting between 10 and 20 randomly selected fields with a Zeiss epifluorescence microscope (model Axioskop 2 plus) at a magnification of 1600x.

\section{Data analysis}

Pearson's correlation and partial correlation analysis (surface stratum: $5-50 \mathrm{~m}$; all data) were used to look for possible associations between variables. Lineal regression analysis was also performed between selected variables. An analysis of variance (ANOVA) was done to detect whether the analyzed variables (i.e. VLP abundance, prokaryotic abundance, temperature, oxygen, salinity, chlorophyll $a$, phaeopigments) varied according to geographic location on the seamount; different stations as well as vertical layers (i.e. 5-20 m, 5-50 m, and $50-150 \mathrm{~m}$ ) were compared. When significant differences were found, the Tukey test was used to identify the stations. All variables were transformed logarithmically $\left(\log _{10}\right)$ before carrying out any statistical analyses.

\section{RESULTS}

\section{Environmental parameters}

The water column was stratified on the seamount, and had a mixed layer around $35 \mathrm{~m}$ depth. Figure 2 shows the hydrographic parameters for each station. The temperature ranged from $17.7^{\circ} \mathrm{C}$ (surface) to $5.6^{\circ} \mathrm{C}$ (bottom) and salinity ranged from 34.31 (surface) to $34.58(200 \mathrm{~m})$. The oxygen levels varied widely along the water column, averaging $5.2 \mathrm{~mL} \mathrm{O}_{2} \mathrm{~L}^{-1}$ at the surface and decaying to $<0.5 \mathrm{~mL} \mathrm{O}_{2} \mathrm{~L}^{-1}$ between 130 and $280 \mathrm{~m}$ depth. These low oxygen conditions reflect the strong influence of the Equatorial Subsurface Waters (ESSW) even at this distance from the shore (Schneider et al., 2003). Below this, the oxygen level increased to a maximum of almost $4 \mathrm{~mL} \mathrm{O}_{2} \mathrm{~L}^{-1}$ around $550 \mathrm{~m}$ depth. 

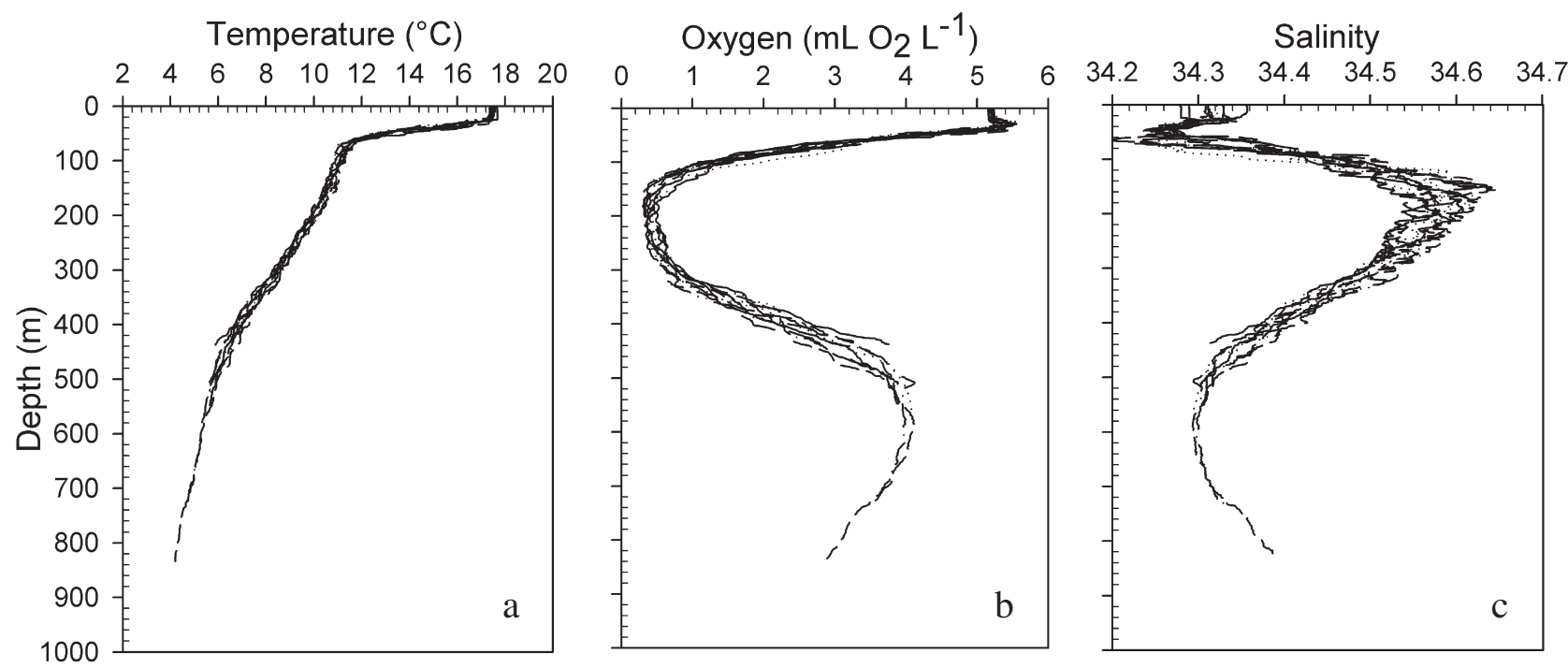

FIG. 2. - Vertical profiles of (a) temperature, (b) oxygen, and (c) salinity at the stations on Bajo O'Higgins 1 seamount.

A subsurface chlorophyll $a$ and phaeopigment maximum was observed at $50 \mathrm{~m}$ depth in most stations (Fig. 3); the respective concentrations ranged from $0.21 \mu \mathrm{g} \mathrm{L}^{-1}$ to $0.55 \mu \mathrm{g} \mathrm{L}^{-1}$ (average $0.41 \pm 0.09$ $\mu \mathrm{g} \mathrm{L}^{-1}$ ) and from $0.15 \mu \mathrm{g} \mathrm{L}^{-1}$ to $0.26 \mu \mathrm{g} \mathrm{L}^{-1}$ (average $0.22 \pm 0.03 \mu \mathrm{g} \mathrm{L}^{-1}$ ). In the BBL samples, the highest concentrations were found in the shallowest bathymetric isolines (400 and $500 \mathrm{~m}$; see Table 1).

\section{Spatial distribution and abundance}

VLP concentrations in the water column decreased with depth at all the stations sampled (Fig. 4a). VLP abundance varied between $10.93 \mathrm{x}$ $10^{9} \mathrm{VLP} \mathrm{L}^{-1}$ and $16.48 \times 10^{9} \mathrm{VLP} \mathrm{L}^{-1}$ (average 13.98 $\left.\pm 1.94 \times 10^{9} \mathrm{VLP} \mathrm{L}^{-1}\right)$ at the surface and decreased to

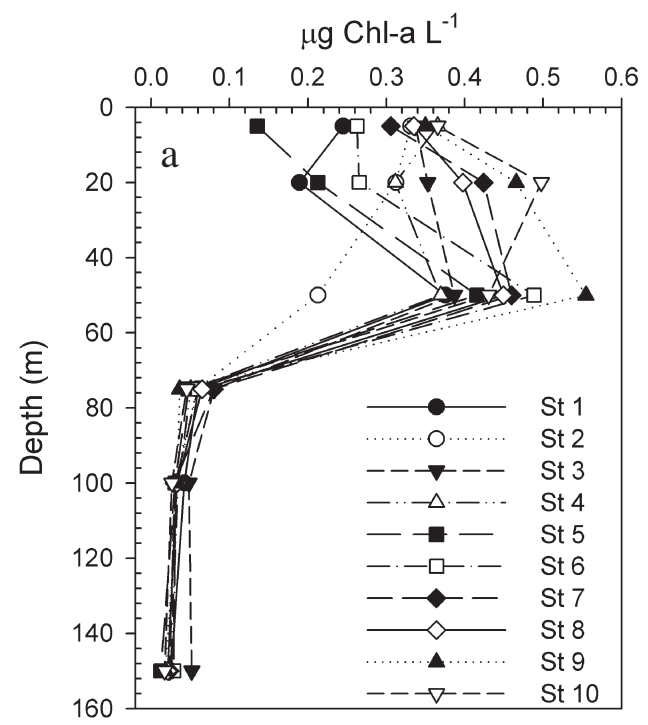

$1.98 \pm 3.12 \times 10^{9} \mathrm{VLP} \mathrm{L}^{-1}$ at $150 \mathrm{~m}$. Likewise, prokaryotic abundance decreased with depth (Fig. 4b), reaching $11.25 \pm 1.99 \times 10^{8}$ cell $\mathrm{L}^{-1}$ in surface waters and $2.92 \pm 0.5 \times 10^{8}$ cell $\mathrm{L}^{-1}$ at $150 \mathrm{~m}$.

In the BBL samples, VLP abundance varied between $0.68 \times 10^{9} \mathrm{VLP} \mathrm{L}^{-1}$ and $1.41 \times 10^{9} \mathrm{VLP} \mathrm{L}^{-1}$ and prokaryotic abundance varied between $0.91 \times 10^{8}$ cell $\mathrm{L}^{-1}$ and $1.72 \times 10^{8}$ cell L-1 (see Table 1). In both cases, the highest concentrations were found over the meseta that constitutes the seamount's peak $(\sim 400 \mathrm{~m})$.

\section{VLP to prokaryote ratio (VP-ratio)}

The VP-ratio in the water column decreased with depth at all stations ranging from an average of 12.56 (surface) to 4.3 (100 m depth). This trend of

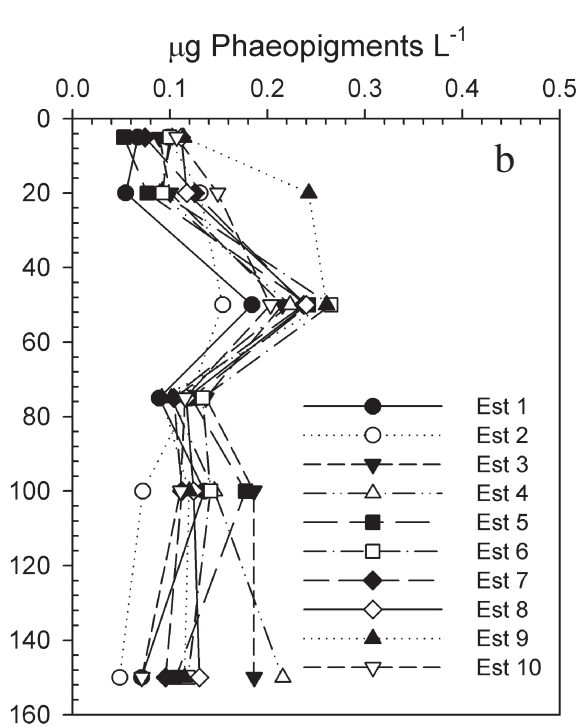

FIG. 3. - Vertical profiles of (a) chlorophyll $a$ and (b) phaeopigments at the stations on Bajo O'Higgins 1 seamount. 

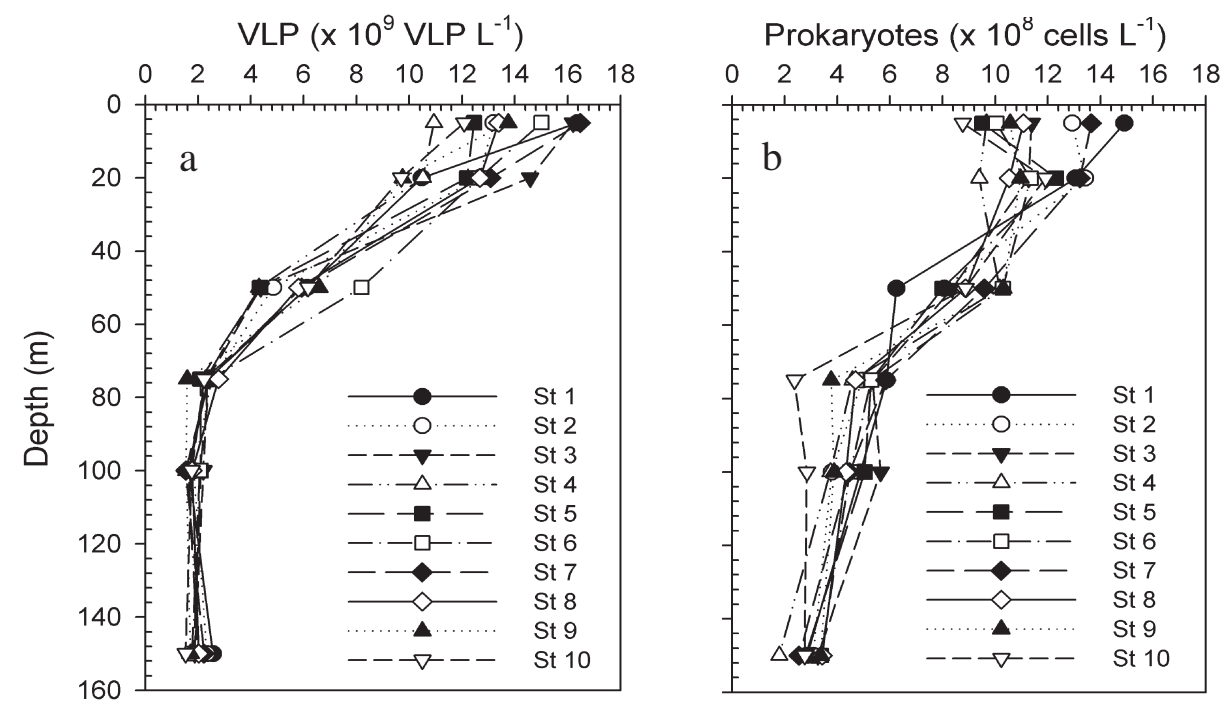

FIG. 4. - Vertical profiles of (a) virus-like particles and (b) prokaryotes at the stations on Bajo O'Higgins 1 seamount.

decreasing with depth reversed upon reaching the OMZ, where the average VP-ratio increased to 7.05 at $150 \mathrm{~m}$ (OMZ; Fig. 5a).

On the other hand, no significant spatial variations were found in the VP-ratio of the BBL samples (Fig. 5b). The average VP-ratio of the BBL was 7.87, slightly higher than that of the OMZ.

\section{Associations between VLP, prokaryotes, and environmental variables}

When analyzing all the data (i.e. water column and BBL samples; $\mathrm{n}=70)$, a high correlation $\left(\mathrm{r}^{2}=\right.$ $0.821, p<0.05)$ was found between viral and prokaryotic abundance. Likewise, VLP were highly associated with chlorophyll $a$, temperature and, to a lesser degree, oxygen (Table 2). Prokaryotic abundance, however, was highly associated with chlorophyll $a$ and temperature and, to a much lesser extent, with oxygen and phaeopigments (Table 2).



An analysis of the surface stratum (between 5 and $50 \mathrm{~m}$ depth) revealed that VLP abundance is moderately correlated with prokaryotic abundance, phaeopigments, and salinity but strongly correlated with temperature and oxygen (Table 2). The environmental homogeneity observed during the cruise in the OMZ (below $150 \mathrm{~m}$ ) and at the BBL does not allow a proper correlation analysis within each of these strata.

When determining the association between VLP and prokaryotic abundance, the co-variance of both variables with environmental variables such as oxygen and temperature must be considered. Furthermore, the environmental variables could be associated with each other. Due to this, a partial correlation analysis was done pooling all the data together (i.e. surface layer, OMZ, and BBL; $\mathrm{n}=70$ ), which revealed a significant relationship between VLP and chlorophyll $a$, phaeopigments, temperature, oxygen, and salinity (Table 3). The partial correlation analysis also showed a significant relation-



FIG. 5. Virus-like particles/prokaryote ratio (VP-ratio) in the (a) water column (5 - $150 \mathrm{~m}$ ) and (b) benthic boundary layer on Bajo O'Higgins 1 seamount. 
TABLE 2. - Correlation coefficients between biotic and abiotic variables in the water column of the Bajo O'Higgins 1 seamount. Sample size for VLP and prokaryotes: all data $(\mathrm{n}=70)$, surface layer (i.e. 5-50 m; $\mathrm{n}=30$ ). All correlation coefficients are significant at $\mathrm{p} \leq 0.05$. (-) No significant correlation $(\mathrm{p}>0.05)$.

\begin{tabular}{lccccccc}
\hline & VLP & Prokaryotes & Chl $a$ & Phaeopigments & Oxygen & Temperature & Salinity \\
\hline $\begin{array}{l}\text { All data } \\
\text { VLP }\end{array}$ & & & & & & & \\
Prokaryotes & 0.90 & 0.90 & 0.89 & 0.28 & 0.55 & 0.79 & -0.39 \\
Surface layer & & & 0.92 & 0.48 & 0.44 & & -0.35 \\
VLP & & & & & & 0.93 & 0.74 \\
Prokaryotes & 0.68 & 0.68 & - & -0.76 & 0.91 & 0.61 & 0.75 \\
\hline
\end{tabular}

TABLE 3. - Partial correlation analysis between biotic and abiotic variables in the water column of the Bajo O'Higgins 1 seamount. Sample size for VLP and prokaryotes: all data $(n=70)$, surface layer (i.e. 5 - $50 \mathrm{~m} ; \mathrm{n}=30$ ). All correlation coefficients are significant at $\mathrm{p} \leq 0.05$. $(-)$ No significant correlation $(\mathrm{p}>0.05)$.

\begin{tabular}{lcccccc}
\hline & Prokaryotes & Chl $a$ & Phaeopigments & Oxygen & Temperature & Salinity \\
\hline VLP (all data) & - & 0.51 & -0.45 & 0.41 & 0.38 & 0.40 \\
VLP $(5-50 \mathrm{~m})$ & 0.45 & - & - & - & - \\
\hline
\end{tabular}

ship between viral abundance and prokaryotic abundance at the surface $(5-50 \mathrm{~m})$ (Table 3$)$.

\section{Between-station comparisons}

Significant differences $(\mathrm{p}<0.05)$ were detected for the surface layer $(5-20 \mathrm{~m}$ depth; $\mathrm{n}=20)$ for prokaryotic abundance, chlorophyll $a$, temperature, oxygen, and salinity. The Tukey test among stations only indicated significant differences for chlorophyll $a$, temperature, and salinity between some stations (data not shown). No significant differences ( $p$ $<0.05$ ) were found for the other analyzed layers (i.e. all the data and 50-150 m.).

\section{DISCUSSION}

This study describes, for the first time, the distribution and abundance of VLP on a seamount and the relationship of this distribution with prokaryotic abundance as well as with environmental factors.

The spatial distribution of chlorophyll $a$ on the seamount did not vary much between sampling stations (Fig. 3a). Nevertheless, this observed homogeneity should be taken with caution considering the short time scale involved in our sampling. The chlorophyll $a$ and phaeopigment levels measured on the seamount are low (Fig 3), but within the ranges reported for adjacent areas (Pizarro et al., 2001). Unfortunately, no information is available on primary production from this area, making it impossible to determine the level of biological productivity for Bajo O'Higgins 1. However, increased levels of phytoplanktonic biomass and productivity were found in areas influenced by seamounts (e.g. Comeau et al., 1995 ) and therefore it is possible that primary productivity could be enhanced on the Bajo O'Higgins 1 seamount in some periods of the year. In fact, the high fishery activity on species such as Orange Roughy (Hoplostethus atlanticus) and Alfonsino (Beryx splendens), which concentrate on this seamount (Young et al., 2000), suggests that the seamount's topography may influence biological and oceanographic processes, therefore enhancing biological productivity. Seamounts can generate physical disturbances that cause water masses to rise from the sea bottom to the photic zone, increasing primary production (Boehlert and Genin, 1987; Sime-Ngando et al., 1992; Pusch et al., 2004) and creating conditions capable of sustaining a high diversity and abundance of organisms (Rowden and Clark, 2004).

With the increase in research in the field of marine virology, it is becoming more evident that virioplankton play a significant role in aquatic communities (e.g. Suttle et al., 1990; Eissler and Quiñones, 2003; Winter et al., 2004). Accordingly, the precision and accuracy of the methods for estimating viral abundance are crucial. However, the discussion regarding the best methodology to be used is on-going. The methodology utilized in this research (i.e. fixation with glutaraldehyde and storing at $4^{\circ} \mathrm{C}$ ) is the most common method used to preserve and store viruses for determining their abundance in aquatic ecosys- 
tems (e.g. Noble and Fuhrman, 1998; Chen et al., 2001; Hewson et al., 2001; Culley and Welschmeyer, 2002; Taylor et al., 2003; Corinaldesi et al., 2003; Glud and Middelboe, 2004; Lunau et al., 2005; Vanucci et al., 2005). Nevertheless, this methodology is becoming controversial because there is evidence showing that it can underestimate viral abundance (Brussaard, 2004; Wen et al., 2004). It is highly likely that there has been a certain level of underestimation with the methodology we used here. We recognize the importance of the role of fixing and storing in estimating viral abundance and, for that matter, bacterial abundance. In fact, Wen et al. (2004) suggest that it is much more reliable to store the samples at $-80^{\circ} \mathrm{C}$. Wen's conclusions are coherent with those of Brussaard (2004), who uses flow cytometry combined with liquid nitrogen, deep freezing $\left(-80^{\circ} \mathrm{C}\right)$, and glutaraldehyde. In contrast, other authors have reached the conclusion that storing at $-80^{\circ} \mathrm{C}$ is more effective only when the objective is to keep the samples for long periods of time (more than 40 days) but that for shorter periods storing at $4^{\circ} \mathrm{C}$ is better (Olson et al., 2004). It is important to note that methodological controversies are frequent in the fields of marine microbiology and biological oceanography. For instance, the controversies concerning the real efficiency of filters of different materials and pore sizes (e.g. Stockner et al., 1990; Lee et al., 1995), the most appropriate methodology for measuring DOC (e.g. Sugimura and Suzuki, 1988; Suzuki et al., 1992; Wangersky, 1993), or even the most adequate methodology for obtaining an optimum measurement of chlorophyll in seawater (e.g. Holm-Hansen and Riemann, 1978; Baker et al., 1983; Stramski, 1990). The history of these controversies has shown that it is necessary to accumulate a large body of evidence before discarding one method and the knowledge obtained from it.

The high VLP abundance observed on the Bajo O'Higgins 1 seamount is consistent with previously published values for other oceanic areas (see Table 4), although it is slightly lower than that observed in the water column over the continental shelf off central Chile (average $2.05 \times 10^{10} \mathrm{VLP} \mathrm{L}^{-1}$; unpublished results). Viral abundance decreases with depth on the seamount (Fig. 4a), which is in accordance with trends previously reported in other oceanic ecosystems (e.g. Hara et al., 1996; Steward et al., 1996). Similarly, the prokaryotic abundance is within the ranges registered off central Chile, especially in oceanic zones of the HCS (e.g. Cuevas et al., 2004). The decreasing prokaryotic vertical distribution observed on Bajo O'Higgins 1 (Fig. 4b) is also consistent with the pattern described for other areas, such as the Adriatic Sea (Corinaldesi et al., 2003) and the North Pacific Ocean (Culley and Welschmeyer, 2002).

The significant correlation found between VLP abundance and prokaryote cells (Table 2) suggests that the members of the latter group are the main hosts for viruses, which is a typical trend in marine systems (e.g. Hara et al., 1996; Weinbauer and Suttle, 1997; Culley and Welschmeyer, 2002). Nevertheless the correlation found between VLP and chlorophyll $a$ (Table 2) suggests that phytoplankton may also play a relevant role as hosts.

Viral distribution and abundance in the ocean can be controlled or modified by environmental factors such as light, temperature, oxygen (e.g. Gantzer et al., 1998; Weinbauer and Höfle, 1998; Bettarel et al., 2003, Corinaldesi et al., 2003), and turbidity (Winter et al., 2005). Likewise, abiotic factors like nutrient availability and temperature affect prokary-

TABLE 4. - Comparison of viral abundance in the water column from oceanic areas. EFM = epifluorescence microscopy; FC = flow cytometry; TEM = transmission electron microscopy. Table extracted and modified from Wommack and Colwell (2000).

\begin{tabular}{|c|c|c|c|c|}
\hline Area & Method & $\operatorname{VLP}\left(\mathrm{x} 10^{6} \mathrm{~mL}^{-1}\right)$ & VBR & Reference \\
\hline North Pacific (subartic) & EFM & $0.06-0.38$ & $1.1-4.5$ & Hara et al. (1996) \\
\hline North Pacific (subtropical) & EFM & $0.4-1.9$ & $1.0-8.7$ & Hara et al. (1996) \\
\hline Equatorial Pacific & $\mathrm{FC}$ & 5.3 & - & Marie et al. (1999) \\
\hline Sargassum Sea & TEM & $0.003 \pm 0.0015$ & - & Proctor and Fuhrman (1990) \\
\hline East Caribbean Sea & TEM & $1.9 \pm 1.3$ & - & Proctor and Fuhrman (1990) \\
\hline West Caribbean Sea & TEM & $4.8 \pm 3$ & - & Proctor and Fuhrman (1990) \\
\hline North Atlantic & TEM & 14.9 & 50 & Bergh et al. (1989) \\
\hline Barents Sea & TEM & 0.06 & 3 & Bergh et al. (1989) \\
\hline Mediterranean Sea & FC & $2.3-6.5$ & - & Marie et al. (1999) \\
\hline Alboran Sea & EFM- TEM & $1.8-0.014$ & $1.4-20$ & Alonso et al. (2001) \\
\hline Baltic Sea (BY 15) & EFM & 23.4 & - & Weinbauer et al. (2002) \\
\hline Baltic Sea (Teili 1) & EFM & 32.9 & - & Weinbauer et al. (2002) \\
\hline North Sea (Stn 112) & EFM & 27.1 & - & Weinbauer et al. (2002) \\
\hline Eastern South Pacific & EFM & $0.68-16.48$ & $4-15$ & Present study \\
\hline
\end{tabular}


ote distribution and abundance (e.g. Brett et al., 1999; Heidelberg et al., 2002). Thus, environmental gradients in the ocean that are able to modify viral or prokaryotic abundance can potentially influence the VLP/prokaryote relationship. Similarly, biotic factors could also modulate the relationship between VLP and prokaryotes such as grazing by protists (i.e. ciliates and flagellates) over prokaryotes (e.g. Fuhrman and Noble, 1995; Cuevas et al., 2004).

The HCS is characterized by sharp vertical gradients, especially of oxygen, generated by the presence of several water masses, namely SubAntarctic Waters (SAAW), ESSW, and Antarctic Intermediate Waters (AAIW) (Strub et al., 1998). The ESSW brought by the Gunther Current is particularly relevant to the present study, since these waters are very poor in dissolved oxygen (Brandhorst, 1971; Sievers and Silva, 1982; Silva, 1983). The environment generated by the OMZ associated with the ESSW represents an important biological barrier for organisms relying on aerobic metabolism (Eissler and Quiñones, 1999). Based on the oxygen vertical distribution (Fig. 2b), three systems were identified in the water column on the Bajo O'Higgins 1 seamount. The surface system (i.e. 0 to $100 \mathrm{~m}$ ) is characterized by high oxygen concentrations $\left(>2 \mathrm{~mL} \mathrm{O}_{2} \mathrm{~L}^{-1}\right.$ ) and influenced by light. The second system is below $100 \mathrm{~m}$ and corresponds largely to ESSW, with extremely low oxygen conditions $(<0.5$ $\mathrm{mL} \mathrm{O}_{2} \mathrm{~L}^{-1}$ ). Finally, at the BBL, oxygen concentrations are higher than at the $\mathrm{OMZ}$ due to the influence of the more oxygenated waters of the AAIW.

Although the microbial assemblages inhabiting the $\mathrm{OMZ}$ of the HCS remain largely unidentified, some evidence indicates that they are very different from those dwelling in oxic waters. For example, the abundance of archaea (Levipan, 2006) and assemblages of denitrifying microorganisms (Molina, 2004; CastroGonzález et al.,2005) are important in the OMZ of the HCS. Consequently, the prokaryote community of the $\mathrm{OMZ}$ is expected to be very different from the microbial communities that live at the surface and bottom of the ocean, which is reflected in the different VP-ratios obtained (Fig. 5). A similar phenomenon was described by Taylor et al. (2003) for variations of viral particles and prokaryotic abundance between three layers (oxic, transitional, and hypoxic) of the water column in Cariaco Basin. These authors found viral distribution to be marked by an environmental oxygen gradient, which was clearly reflected in VP-ratios; the higher proportions corresponded to the hypoxic zone. Similarly, Weinbauer et al. (2003) showed an incre- ment in the abundances of both VLP and prokaryotes in anoxic waters of the Baltic Sea. In fact, the same trend was observed in the present study, where the VPratios decreased with depth in the oxic zone and then drastically increased under hypoxic conditions.

The differential VLP/prokaryote association with respect to environmental gradients on the Bajo O'Higgins 1 seamount could be due to the fact that the microbial assemblage compositions, particularly for prokaryotes, are very different in these layers (i.e. surface, OMZ, BBL). A low VPratio may indicate that the observed relationship between VLP and host prokaryotic cells could be explained by the presence of a low infecting rate, a low number of viruses per available host cell, or a high virus decay rate (Alonso et al., 2001). In addition, the difference in the VP-ratios could be caused by virus-host specificity (Middelboe et al., 2000) or the different viral assemblages found in the oxic and hypoxic layer. Another alternative hypothesis for the lack of correlation between VLP and prokaryotes and the high VP-ratio in the OMZ is a relative increase in virioplankton not able to infect the existing prokaryotes, as Bettarel et al. (2003) observed in some lakes.

In contrast to the rest of the water column, no change in the VP-ratio associated with the dissolved oxygen content was observed in the BBL, probably due to the spatial variability of the community living in the sediment. It is known that the BBL is strongly influenced by the resuspension of organic matter (Schallenberg and Burns, 2004), sinking of POM from surface layers (Turley, 2000), and degradation processes acting on the organic matter found at the sea bottom (Suess, 1980; Peterson et al., 1988; Graco et al., 2001).

Given these results, we conclude that the association between viral and prokaryotic abundance is significantly shaped by the environmental conditions, mainly dissolved oxygen concentration in the water column associated with the Bajo O'Higgins 1 seamount.

\section{ACKNOWLEDGEMENTS}

We wish to thank Silvio Pantoja and Luis Antonio Cuevas for their useful comments on an earlier version of this manuscript. We also thank the cooperative Chilean-Japanese Cooperation Program (National Fisheries University, Japan; Universidad 
Austral de Chile; Undersecretariat of Fisheries, Chilean Government) and Mr. Alejandro Zuleta (CEPES, Universidad Austral de Chile) for the opportunity to participate in the R/V Koyo Maru cruise. We extend our appreciation to the captain and crew of the R/V Koyo Maru, and particularly to First Officer Tadashi Kamano. Furthermore, we are grateful to Raul Gili, Gerdhard Jessen, and Karol Espejo, who contributed with logistic support for the expedition; and to Pedro Inostroza, Cristian Chandía, and María Inés Muñoz, who were of great assistance during on board sampling. We would also like to recognize Eduardo Navarro and Rodrigo Montes for providing support in data processing and analysis. This research was funded by the COPAS Center (FONDAP, CONICYT).

\section{REFERENCES}

Alonso, M.C.,F. Jiménez-Gómez, J. Rodríguez and J.J. Borrego. 2001. Distribution of virus-like particles in a oligotrophic marine environment (Alborean sea, Western Mediterrean). Microb. Ecol., 42: 407-415.

Antezana, T. - 1978. Distribution of Euphausiids in the Chile-Perú Current with particular reference to the endemic Euphausia mucronata and the oxygen minima layer. $\mathrm{Ph} . \mathrm{D}$. thesis, Univ. California.

Arana, P. - 1987. Perspectiva histórica y proyecciones de la actividad pesquera realizada en el Archipiélago de Juan Fernández, Chile. In: J.C. Castilla (ed.), Islas oceánicas chilenas: Conocimiento científico y necesidades de investigaciones, $\mathrm{pp}$. 319-353. Editorial Universidad Católica de Chile.

Azam, F., T. Fenchel, J.G. Field, J.S. Gray, L.A. Meyer-Reil and F. Thingstad. - 1983. The ecological role of water-column microbes in the sea. Mar. Ecol.Prog. Ser., 10: 257-263.

Baker, K.S., R.C. Smith, and J.R. Nelson. - 1983. Chlorophyll determinations with filter fluorometer: Lamp/filter combination can minimize error. Limnol. Oceanogr., 28: 1037-1040.

Bergh, Ø., K.Y. Børsheim, G. Bratbak and M. Heldal. - 1989. High abundance of viruses found in aquatic environments. Nature, 340: 467-468.

Bettarel, Y., T. Sime-Ngando, C. Amblard, J.F. Carrias and C. Portelli. - 2003. Virioplankton and microbial communities in aquatic systems: a seasonal study in two lakes of differing trophy. Freshw. Biol., 48: 810-822.

Boehlert, G.W. and A. Genin. - 1987. A review of the effects of seamounts on biological processes. In: B.H. Keating, P. Fryer, R. Batiza and G.W. Boehlert (eds.), Seamounts, islands and atolls. Geophys. Monograph, 43: 319-334.

Brandhorst, W. - 1971. Condiciones oceanográficas estivales frente a la costa de Chile. Rev. Biol. Mar., 14: 45-84

Bratbak, O., M. Hendal, S. Norland, and T.F. Thingstad. - 1990. Viruses as patterns in spring bloom microbial trophodynamics. Appl. Environ. Microbiol., 56: 1400-1405.

Brett M.T., F.S. Lubnow, M. Villar-Argaiz, A. Müller-Solger and C.R Goldman. - 1999. Nutrient control of bacterioplankton and phytoplankton dynamics. Aquat. Ecol., 33: 135-145.

Brussaard, C.P.D. -2004 . Optimization of procedure for counting viruses by flow citometry. Appl. Environ. Microbiol., 70: $1506-1513$

Castro-González, M. - 2004. La importancia de la comunidad desnitrificante en el reciclamiento del $\mathrm{N}_{2} \mathrm{O}$ en la Zona de Mínimo de Oxígeno (ZMO) del norte de Chile. Doctorate Thesis, Univ. Concepción.

Castro-González, M. G. Braker, L. Farías and O. Ulloa. - 2005. Communities of nirS type denitrifiers in the water column of the oxygen minimum zone in the Eastern South Pacific. Environ. Microbiol., 7: 1298-1306.

Chen, F., J. Lu, B.J. Binder, Y. Liu and R.D. Hodson. - 2001. Application of digital image analysis and flow cytometry to enumerate marine viruses stained with SYBR Gold. Appl. Environ. Microbiol., 67: 539-545.

Cochlan, W.P. J. Wikner, G.F. Steward, D.C. Smith, and F. Azam. - 1993. Spatial distribution of viruses, bacteria and chlorophyll $a$ in neritic, oceanic and estuarine environments. Mar. Ecol. Prog. Ser., 92: 77-87.

Comeau, L.A., A.F. Vézina, M. Bourgeois and K. Juniper. - 1995. Relationship between phytoplankton production and the physical structure of the water column near Cobb Seamount, Northeast Pacific. Deep-Sea Res., 42: 993-1005.

Corinaldesi, C., E. Crevatin, P.D. Negro, M. Marini, A. Russo, S. Fonda-Umani and R. Danovaro. - 2003. Large-scale distribution of virioplankton in the Adriatic Sea: testing the trophic state control hypothesis. Appl. Environ. Microbiol., 69: 2664-2673.

Cuevas, L.A., G. Daneri, B. Jacob and P. Montero. - 2004. Microbial abundance and activity in the seasonal upwelling area off Concepción $\left(\sim 36^{\circ} \mathrm{S}\right)$, central Chile: a comparison of upwelling and non-upwelling conditions. Deep-Sea Res. II, 51: $2427-2440$.

Culley, A.I. and N.A. Welschmeyer. - 2002. The abundance, distribution, and correlation of viruses, phytoplankton, and prokaryotes along a Pacific Ocean transect. Limnol. Oceanogr., 47: $1508-1513$

Drake, L.A., K.H. Choi, A.G.E. Haskell and F.C. Dobbs. - 1998. Vertical profiles of virus-like particles and bacteria in the water column and sediments of Chesapeake Bay, USA. Aquat. Microb. Ecol. 16: 17-25.

Eissler, Y. and R.A. Quiñones. - 1999. Microplanktonic respiration off northern Chile during El Niño 1997-1998. J. Plankton Res., 21: $2263-2283$

Eissler, Y. and R.A. Quiñones. - 2003. The effect of viral concentrate addition on the respiration rate of Chaetoceros gracilis cultures and microplankton from a shallow bay (Coliumo, Chile). J. Plankton Res., 25: 927-938.

Fuhrman, J.A. and R.T. Noble. - 1995. Viruses and protists cause similar bacterial mortality in coastal seawater. Limnol. Oceanogr., 40: 1236-1242.

Fuhrman, J.A. - 1999. Marine viruses and their biogeochemical an ecological effects. Nature, 399: 541-548.

Gantzer, C., E. Bubois, J.M. Crance, S. Billaudel, H. Kopecka, L. Schwartzbrod, M. Pommepuy and F. Le Guyader. - 1998. Influence of environmental factors on the survival enteric viruses in seawater. Oceanol. Acta, 21: 983-992.

Glud, R.N. and M. Middelboe. - 2004. Virus and bacteria dynamics of a coastal sediments: Implication for benthic carbon cycling. Limnol. Oceanogr. 49: 2073-2081.

González, R.R. and R.A. Quiñones. - 2002. LDH activity in Euphausia mucronata and Calanus chilensis: implications for vertical migration behaviour. J. Plankton Res., 24: 1349-1356

Graco, M., L. Farias, V. Molina, D. Gutiérrez and L.P. Nielsen. 2001. Massive develop of microbial mats following phytoplankton blooms in a natural eutrophic bay: Implications of the nitrogen cycling. Limnol. Oceanogr., 46: 821-832

Holm-Hansen, O. and B. Riemann. - 1978. Chlorophyll $a$ determination: improvements in methodology. Oikos, 30: 438-447.

Hara, S., I. Koike, K. Terauchi, H. Kamiya and E. Tanoue. - 1996. Abundance of viruses in deep oceanic water. Mar. Ecol. Prog. Ser., 145: 269-277.

Heidelberg, J.F., K.B. Heidelberg and R.R. Colwell. - 2002. Seasonality of Chesapeake Bay Bacterioplankton species. Appl. Environ. Microbiol., 68: 5488-5497.

Hewson, I. J.M. O'Neil, J.A. Fuhrman and W. C. Dennison. - 2001. Virus-like particles distribution and abundance in sediments and overlying waters along eutrophication gradients in two subtropical estuaries. Limnol. Oceanogr. 46: 1734-1746.

Judkins, D. C. - 1980. Vertical distribution of zooplankton in relation to the oxygen minimum off Peru. Deep-Sea Res. A, 27: 475-487.

Lee, S., Y.C. Kang and J.A. Fuhrman. - 1995. Imperfect retention of natural bacterioplankton cells by glass-fiber filters. Mar. Ecol.Prog. Ser., 119: 285-290.

Levipan, H. - 2006. Incorporación heterotrófica de leucina por Arquea en la columna de agua de la plataforma continental de 
Concepción. M. Sc. Thesis. Univ. Concepción.

Lunau, M., A. Lemke, K. Walther, W. Martens-Habbena and M. Simon. - 2005. An improved method for counting bacteria from sediments and turbid environments by epifluorescence microscopy. Environ. Microbiol., 7: 961-968.

Marie, D., C.P.D. Brussard, R. Thyrhaug, G. Bratbak and D. Vaulot. - 1999. Enumeration of marine viruses in culture and natural samples by flow cytometry. Appl. Environ. Microbiol., 65: 45-52.

Middelboe, M. - 2000. Bacterial growth rate and marine virus-host dynamics. Microb. Ecol., 40: 114-124.

Molina, V. - 2004. Nitrificación en un fuerte gradiente de oxígeno asociado a la zona de mínima de oxígeno del Pacífico SurOriental $\left(\sim 21\right.$ y $\left.23{ }^{a} \mathrm{~S}\right)$. Ph. D. Thesis. Univ. Concepción.

Morales, E. - 1985. El Pacífico del sudeste, sus islas oceánicas y problemas asociados. In: P. Arana (ed.), Investigaciones marinas del Archipiélago de Juan Fernández, pp 15-23. Universidad Católica de Valparaíso, Valparaíso.

Noble, R.T. and J.A. Fuhrman. - 1998. Use of SYBR Green I for rapid epifluorescence counts of marine viruses and bacteria. Aquat. Microb. Ecol., 14: 113-118.

Olson, M.R., R.P. Axlera and R.E. Hicks. - 2004. Effects of freezing and storage temperature on MS2 viability. J. Virol. Methods, 122: 147-152

Parson, T.R., Y. Maita, and C.M Lalli. - 1984. A Manual of chemical and biological methods for seawater analysis. Pergamon Press, Elmsford.

Peterson, W.T., D.F. Arcos, G.B. McManus, H. Dam, D. Bellantoni, T. Johnson and P. Tiselius. - 1988. The nearshore zone during coastal upwelling: Daily variability and coupling between primary and secondary production of Central Chile. Prog. Oceanogr., 20: 1-40.

Pizarro, G., R. Astoreca, G. Alarcón, V. Montecino and L. Guzmán. - 2001. Variabilidad espacial del fitoplancton de primavera: Bases para la estimación de biomasa mediante sensores remotos. (Entre Valparaíso-Archipiélago de Juan Fernández-islas Desventuradas). Taller sobre los resultados del Crucero Cimar 6 Islas Oceánicas.

Proctor, L.M. and J.A. Fuhrman. - 1990. Viral mortality of marine bacteria and cyanobacteria. Nature, 343: 60-62.

Pusch, C., A. Beckmann, F. Mora Porteiro and H. Von Westernhagen. -2004 . The influence of seamounts on mesopelagic fish communities. Arch. Fish. Mar. Res., 51: 165-186.

Rowden, A. and M. Clark. - 2004. Uncovering secrets of our seamounts. Water \& Atmosphere, 12: 22-23.

Schallenberg, M. and C.W. Burns. - 2004. Effects of sediment resuspension on phytoplankton production: teasing apart the influences of light, nutrients and algal entrainment. Freshw. Biol., 49: 143-159.

Schneider, W., R. Fuenzalida, E. Rodríguez-Rubio, J. GarcésVargas and L. Bravo. - 2003. Characteristics and formation of Eastern South Pacific Intermediate Water. Geophys. Res. Lett., 30: 1581, doi:10.1029/2003GL017086

Sievers, H.A. and N. Silva. - 1982 Masas de agua y circulación geostrófica frente a la costa de Chile entre latitudes $18^{\circ} \mathrm{S}$ y $33^{\circ} \mathrm{S}$ (Operación oceanográfica MARCHILE VII). Cienc. Tec. Mar. CONA, 6: 61-99.

Silva, N. - 1983. Masas de agua y circulación en la región del norte de Chile, latitudes $18^{\circ} \mathrm{S}-32^{\circ} \mathrm{S}$ (Operación Oceanográfica Mar Chile XI-ERFEN II). Cienc. Téc. Mar. CONA, 7: 47-84.

Sime-Ngando, T., K. Juniper and A. Vézina. - 1992. Ciliated protozoan communities over Cobb Seamount: increase in biomass and spatial patchiness. Mar. Ecol. Prog. Ser., 89: 37-51.

Spencer, R. - 1955. A marine bacteriophage. Nature, 175: 690-691.

Steward, G.F., D.C. Smith and F. Azam. - 1996. Abundance and production of bacteria and viruses in the Bering and Chukchi Seas. Mar. Ecol. Prog. Ser., 131: 287-300.

Stockner, J.G., M.E. Klut and W.P. Cochlan. - 1990. Leaky filter: a warning to aquatic ecologists. Can. J. Fish. Aquat. Sci., 47: 16-23.

Stramski, D. - 1990. Artifacts in measuring absorption-spectra of phytoplankton collected on a filter. Limnol. Oceanogr., 35: 1804-1809.

Strub, P.T., J.M. Mesías, V. Montecino and J. Rutllant. - 1998. Coastal ocean circulation off western South America. In: Robinson, A.R. and K.H. Brink (eds.), The global coastal ocean, pp. 273-313. The Sea, Vol. 11. Interscience, New York.
Suess, E. - 1980. Particulate organic flux in the ocean: Surface productivity and oxygen utilization. Nature, 288: 260-263.

Sugimura, Y. and Y. Suzuki. - 1988. A high temperature catalytic oxidation method for the determination of non-volatile dissolved organic carbon in seawater by direct injection of a liquid sample. Mar. Chem., 24: 105-131.

Suzuki, Y., E. Tanoue and H. Ito. - 1992. A high-temperature catalytic oxidation method for the determination of dissolved organic carbon in seawater: analysis and improvement. DeepSea Res., 39: 185-198.

Suttle, C.A., A.M. Chan and M.T. Cottrell. - 1990. Infection of phytoplankton by viruses and reduction of primary productivity. Nature, 347: 467-469.

Taylor, G.T., C. Hein and M. Iabichella. - 2003. Temporal variations in viral distributions in the anoxic Cariaco Basin. Aquat. Microb. Ecol., 30: 103-116.

Torella, F. and R.Y. Morita. - 1979. Evidence by micrograph for a high incidence of bacteriophage particles in the water of Yaquina Bay, Oregon: ecological and taxonomical implication. Appl. Environ. Microbiol., 37: 774-778.

Turley, C. - 2000. Bacteria in the cold deep-sea benthic boundary layer and sediment-water interface of the NE Atlantic. FEMS Microbiol. Ecol., 33: 89-99.

Ulloa, O. - 2003. Photosynthesis in the oxygen minimum zone of the eastern South Pacific. In: Proceed NATO, Adv. Res. Workshop: 103.

Valentine, A.F., P.K. Chen, R.R. Colwell and G.B. Chapman. 1966. Structure of a marine bacteriophage as revealed by the negative-staining technique. J. Bacteriol., 91: 819-822.

Vanucci, S., V. Bruni and G. Pulicano. - 2005. Spatial and temporal distribution of virioplankton and bacterioplankton in a Brackish Environment (Lake of Ganzirri, Italy). Hydrobiologia 539: 83-92.

Wangersky, P.J. - 1993. Dissolved organic carbon methods: a critical review. In: J.I. Hedges. and C. Lee (eds.), Measurements of dissolved organic carbon and nitrogen in natural water. Mar. Chem., 41: 61-74.

Weinbauer, M.G. - 2004. Ecology of prokaryotic viruses. FEMS Microbiol. Rev., 28: 127-181.

Weinbauer, M.G. and M.G. Höfle. - 1998. Significance of viral lysis and flagellate grazing as factors controlling bacterioplankton production in a eutrophic lake. Appl. Environ. Microbiol., 64: 431-438.

Weinbauer, M.G. and C.A. Suttle. - 1997. Comparison of epifluorescence and transmission electron microscopy for counting viruses in natural marine waters. Aquat. Microb. Ecol., 13: 225-232.

Weinbauer, M.G., D. Fuks and P. Peduzzi. - 1993. Distribution of viruses and dissolved DNA along a coastal trophic gradient in the Northern Adriatic Sea. Appl. Environ. Microbiol., 59: 4074-4082.

Weinbauer, M.G., C. Winter and M.G. Höfle. - 2002. Reconsidering transmission electron microscopy based estimates of viral infection of bacterioplankton using conversion factors derived from natural communities. Aquat. Microb. Ecol., 27: 103-110.

Weinbauer, M.G., I. Brettar and M.G. Höfle. - 2003. Lysogeny and virus-induced mortality of bacterioplankton in surface, deep, and anoxic marine water. Limnol. Oceanogr., 48: 1457-1465.

Wen, K., A.C. Ortmann and C. Suttle. - 2004. Accurate estimation of viral abundance by epifuorescence microscopy. Appl. Environ. Microbiol., 70: 3862-3867.

Winter, C., G. Herndl and M.G. Weinbauer. - 2004. Diel cycles in viral infection of bacterioplankton in the North Sea. Aquat. Microb. Ecol., 35: 207-216.

Winter, C., A. Smit, T. Szoeke-Dénes, G.J. Herndl and M.G. Weinbauer. - 2005. Modelling viral impact on bacterioplankton in the North Sea using artificial neural networks. Environ. Microbiol., 7: 881-893.

Wommack, K.E. and R.R Colwell. - 2000. Virioplankton: Viruses in the aquatic ecosystems. Microbiol. Mol. Biol. Rev., 64: 69-114.

Young, Z., F. Balbontin, J. Rivera, M.I. Ortego, R. Taschero, M. Rojas and S. Lillo. - 2000. Estudio biológico-pesquero del recurso Orange Roughy. Informe final. Investigación y Fomento Pesquero. FIP $N^{\circ}$ 99-05.

Scient. ed.: D. Vaqué.

Received November 7, 2005. Accepted July 5, 2006.

Published online February 6, 2007. 